\title{
PEMANFAATAN GARAM SEBAGAI BAHAN STABILISASI TANAH LEMPUNG DI KALIMANTAN TENGAH
}

\author{
Hendra Cahyadi ${ }^{\left(1^{*}\right)}$ dan Nirwana Puspasari ${ }^{(2)}$ \\ Program Studi Teknik Sipil Universitas Lambung Mangkurat \\ ${ }^{*}$ Email: hendra.cahyadi@ umpalangkaraya.ac.id
}

\begin{abstract}
ABSTRAK
Sebuah struktur bangunan dibangun di atas tanah. Untuk itu sifat-sifat yang dimiliki tanah perlu untuk diketahui agar perencanaan sebuah struktur bangunan bisa dilakukan dengan baik. Tanah yang memiliki sifat yang buruk akan menimbulkan dampak negatif bagi bangunan yang ada di atasnya. Beberapa sifat tanah yang buruk adalah daya dukung yang rendah, memiliki plastisitas tinggi, kembang susut besar hingga kekuatan geser yang rendah. Beberapa parameter sifat tanah yang biasa digunakan adalah nilai CBR dan UCS. Semakin tinggi nilai CBR dan UCS maka semakin baik sifat tanah begitu pula sebaliknya.

Tanah lempung umumnya memiliki nilai CBR dan UCS yang rendah, sehingga bisa dikatakan tanah lempung memiliki sifat yang kurang baik. Di Kalimantan Tengah rendahnya harga CBR dan UCS tanah lempung dipengaruhi oleh dominannya butiran halus sehingga mudah dipengaruhi oleh air. Beberapa upaya untuk memperbaiki sifat tanah lempung telah dilakukan diantaranya dengan stabilisasi tanah. Salah satu bahan stabilisasi tanah lempung yang bisa digunakan adalah garam. Penggunaan garam sebagai bahan stabilisasi tanah lempung bisa memberikan manfaat ekonomi karena harganya yang lebih murah dibanding bahan stabilisasi lain seperti bahan kimia, pasir maupun semen. Tujuan penelitian ini adalah untuk mengetahui nilai CBR dan UCS tanah lempung di Kalimantan Tengah sebelum dan sesudah distabilisasi dengan menggunakan garam.

Penelitian dilakukan di Laboratorium Mekanika Tanah Universitas Muhammadiyah Palangkaraya. Sampel tanah lempung akan diambil di 6 (enam) Kabupaten yang ada di Provinsi Kalimantan Tengah. Uji yang dilakukan terhadap tanah lempung adalah uji CBR dan uji UCS baik sebelum maupun sesudah di stabilisasi dengan garam. Campuran garam yang direncanakan adalah sebesar 5, 10,15,20, 25\% dan 30\% terhadap berat isi kering lempung.

Berdasarkan hasil penelitian menunjukan bahwa nilai CBR tanah asli berkisar antara 3,90\% sampai $4,75 \%$, sehingga dapat dikategorikan sebagai tanah yang memiliki daya dukung yang buruk/rendah. Kemudian setelah dilakukan stabilisasi 5\% sampai $15 \%$, nilai CBR cenderung naik mencapai harga 5\% sampai $9 \%$. Namun setelah dicampur dengan garam sebanyak 20\% sampai 30\%, nilai CBR tanah cenderung menurun dengan signifikan. Dari hal tersebut dapat diambil kesimpulan bahwa nilai CBR mencapai nilai yang maksimum dengan penambahan garam sebesar $10 \%$ sampai15\% dari berat tanah.
\end{abstract}

\section{Kata kunci : stabilisasi, lempung, garam, CBR}


Pemanfaatan Garam sebagai Bahan Stabilisasi Tanah Lempung...Hendra Cahyadi ${ }^{(1)}$, Nirwana Puspasari ${ }^{(2)}$

\section{PENDAHULUAN}

Stabilisasi tanah adalah usaha untuk merubah atau memperbaiki sifat-sifat teknis tanah agar memenuhi syarat teknis tertentu. Sifat-sifat teknis tanah seperti daya dukung (CBR) maupun kuat tekan bebas (UCS) tanah lempung umumnya sangat rendah. Seperti halnya, tanah lempung di Kalimantan Tengah diantaranya di Palangka Raya yang memiliki daya dukung rendah dengan CBR hanya 3,20\% (Nasrullah, 2010) dan 3,50\% (Anwar Muda, 2011). Sedangkan Nirwana dan Hendra (2015) pada penelitiannya mendapatkan nilai CBR 4,60\% untuk tanah di Desa Bukit Rawi, Kalimantan Tengah. Dilihat dari klasifikasi tanah berdasarkan nilai CBR (Bowles, 1992), tanah tersebut termasuk kategori buruk karena berada dalam rentang nilai CBR 3-7\% dengan kegunaan sebagai subgrade.

Kemudian kuat tekan bebas (UCS) tanah lempung juga mengalami hal yang sama yaitu kuat tekannya sangat rendah. Misalnya tanah lempung Ciawi dengan nilai UCS $0,65 \mathrm{~kg} / \mathrm{cm}^{2}$ (Wahjuningsih, 1997) dan tanah lempung Indramayu dengan nilai UCS $0,195 \mathrm{~kg} / \mathrm{cm}^{2}$ (Sudirja, 2008). Sedangkan untuk di Kalimantan Tengah, penelitian yang pernah dilakukan menemukan data bahwa tanah lempung di Palangka Raya mempunyai nilai UCS sebesar $0,473 \mathrm{~kg} / \mathrm{cm}^{2}$ (Anwar Muda, 2011) dan tanah lempung Bukit Rawi dengan nilai UCS sebesar $0,98 \mathrm{~kg} / \mathrm{cm}^{2}$ (Nirwana dan Hendra, 2015). Jika dilihat nilai kuat tekan bebas tanah tersebut maka tanah tersebut termasuk lempung sangat lunak sampai sedang dengan nilai UCS $0-1,00 \mathrm{~kg} / \mathrm{cm}^{2}$ (Hardiyatmo, 2006).

Berdasarkan hal tersebut di atas, maka perlu adanya stabilisasi tanah lempung terutama di Provinsi Kalimantan Tengah untuk meningkatkan daya dukung maupun kuat tekan bebasnya. Pada penelitian kali ini stabilisasi tanah lempung Kalimantan Tengah dilakukan dengan penambahan garam sebagai stabilizing agent untuk mengurangi tekanan pengembangan tanah lempung. Campuran garam yang direncanakan adalah sebesar 5, 10,15,20 dan 25\% terhadap berat isi kering lempung. Penetapan nilai campuran ini didasarkan hasil penelitian Sudjianto (2007) dan Nirwana dan Hendra (2015). Pada campuran tersebut dilakukan pengujian berat jenis, pemadatan standar, CBR serta UCS.

\section{LANDASAN TEORI}

\section{Distribusi Ukuran Butir}

Sifat-sifat tanah sangat tergantung pada ukuran butirannya. Besarnya butiran dijadikan dasar untuk pemberian nama dan klasifikasi tanah. Oleh karena analisis ukuran butiran merupakan penentuan persentase berat butiran pada satu unit saringan dengan ukuran diameter lubang tertentu. Pada umumnya pengukuran analisis ukuran butiran dapat dilakukan dengan 2 cara yaitu analisis ayakan (sieve analysis) dan analisis pengendapan (hydrometer analysis).

\section{Indeks Plastisitas (PI)}

Umumnya tanah berbutir halus secara alamiah berada pada dalam kondisi plastis. Batas atas dan bawah dari rentang kadar air dimana tanah masih bersifat plastis berturut-turut disebut batas cair $(L L)$ dan batas plastis $(P L)$. Rentang kadar air itu sendiri didefenisikan sebagai indeks plastisitas $(P I)$, seperti pada persamaan

$P I=L L-P L$

\section{Berat Jenis (Gs)}

Berat jenis (Gs) bertujuan untuk menentukan berat jenis tanah yang mempunyai butiran lolos saringan no.4, no.10 dan no.40 dengan piknometer, yang mana hasil perbandingan antara berat butiran padat $(\gamma \mathrm{s})$ dengan berat volume air suling $(\gamma \mathrm{w})$ dengan isi yang sama pada temperatur $25^{\circ} \mathrm{C}$ seperti pada persamaan

$$
G_{\mathrm{s}}=\frac{\gamma S}{\gamma w}
$$

\section{Pemadatan (Compaction)}

Untuk menentukan hubungan kadar air dengan berat volume, dan untuk mengevaluasi tanah agar memenuhi persyaratan kepadatan, maka umumnya dilakukan uji pemadatan. Menurut Proctor (1933) (Dalam Hardiyatmo, 2006), telah mengamati bahwa ada hubungan yang pasti antara kadar air dan berat volume kering tanah padat. Untuk berbagai jenis tanah pada umumnya, terdapat satu nilai kadar air optimum tertentu untuk mencapai berat volume kering maksimumnya. Hubungan berat volume kering $(\gamma \mathrm{d})$ dengan berat 
volume basah $(\gamma \mathrm{b})$ dan kadar air (w) dinyatakan dalam persamaan

$$
\gamma d=\frac{\gamma b}{1+w}
$$

\section{California Bearing Ratio (CBR)}

Uji CBR berasal dari Departemen Transportasi California tahun 1929. uji ini dimaksudkan untuk menentukan kelayakan suatu lapisan yanah yang akan digunakan sebagai subbase atau base course dalam konstruksi jalan raya. Sejak perang dunia kedua, U.S Army Corps of Engineers mengadaptasi uji ini untuk digunakan dalam konstruksi lapangan terbang.

Harga CBR adalah perbandingan antara beban penetrasi suatu bahan terhadap bahan standar dengan kedalaman dan kecepatan penetrasi yang sama.

Dalam bentuk rumus:

$\mathrm{CBR}=($ tegangan uji/tegangan baku $) \times 100 \%$.

\section{Unconfined Compressive Strength (UCS)}

Pengujian ini dimaksudkan untuk menentukan besarnya kekuatan tekan bebas contoh tanah berbentuk silinder dalam keadaan asli (undisturbed) maupun tidak asli (compacted or remoulded). Kuat tekan bebas adalah besarnya beban aksial persatuan luas pada saat regangan aksial mencapai $20 \%$. Pembacaan beban dilakukan pada regangan $0,5 \%, 1 \%, 2 \%$ dan seterusnya dengan kecepatan regangan di ambil 0,5\% -2\% per menit, biasanya di ambil $1 \%$ per menit. Pengujian dilakukan sampai mengalami keruntuhan. Keruntuhan dapat di lihat dan makin kecilnya beban, walaupun regangan makin besar. Jika regangan mencapai $20 \%$, tetapi benda uji belum runtuh maka pekerjaan dihentikan.

\section{Garam Dapur}

Struktur $\mathrm{NaCl}$ meliputi anion di tengah dan kation menempati pada rongga octahedral. Larutan garam merupakan suatu elektrolit, yang mempunyai gerakan brown dipermukaan yang lebih besar dari gerakan brown pada air murni sehingga bisa menurunkan air dan larutan ini menembah gaya kohesi antar partikel sehingga ikatan partikel menjadi lebih rapat (Bowles, 1984), selain itu larutan ini bisa memudahkan didalam memadatkan tanah (Ingles dan Metcalf, 1972). Stabilitas tanah adalah upaya yang dilakukan untuk memperbaiki sifat-sifat asal tanah pada dasarnya stabilisasi yang menggunakan garam mempunyai prinsip yang sama dengan stabilisasi yang menggunakan zat kimia lainnya. Keuntungan yang dihasilkan adalah menaikkan kepadatan dan menambah kekuatan tanah. Tanah dengan LL (liquit limits) yang tinggi biasanya memberikan reaksi yang bagus dengan penambahan garam ini (Ingles dan Metcalf, 1972).

\section{Tujuan Penelitian}

Tujuan dari penelitian ini, antara lain :

1. Menentukan sifat-sifat tanah asli pada pengujian distribusi ukuran butir, berat jenis, indeks plastisitas (PI), pemadatan standar, CBR dan UCS.

2. Menentukan indeks plastisitas (PI) tanah lempung setelah distabilisasi menggunakan garam dapur.

3. Menentukan nilai CBR dan UCS tanah lempung sebelum dan sesudah distabilisasi dengan garam dapur.

\section{Manfaat Penelitian}

Pada umumnya lapis pondasi jalan terbuat dari batu pecah. Namun tidak menutup kemungkinan menggunakan tanah yang diperbaiki mutunya (stabilisasi) untuk lapis pondasi jalan. Sekarang timbul pertanyaan, apakah tanah di Kelurahan Bukit Rawi dapat diperbaiki mutunya (stabilisasi) dengan garam dapur?

Sementara tanah yang ada di Bukit Rawi termasuk jenis lempung yang memiliki nilai daya dukung (CBR) dan kuat tekan bebas (UCS) rendah dan didominasi butiran halus sehingga mudah dipengaruhi oleh air, mempunyai plastisitas rendah sampai sedang dengan penilaian sebagai tanah dasar sedang sampai buruk.

Dengan penelitian ini diharapkan akan hasil diperoleh nilai California Bearing Ratio (CBR) dan Unconfined Compression Strength (UCS) sebelum dan sesudah distabilisasi garam dapur. 
Pemanfaatan Garam sebagai Bahan Stabilisasi Tanah Lempung...Hendra Cahyadi ${ }^{(1)}$, Nirwana Puspasari ${ }^{(2)}$

\section{METODE PENELITIAN}

\section{Umum}

Adapun proses penelitian ini dilakukan dengan tahapan - tahapan sebagai berikut :

a. Pengambilan contoh

b. Pengujian contoh tanah

C. Pembuatan campuran tanah dengan garam dapur

d. Pengujian campuran tanah dengan garam dapur

Proses penelitian di atas dijelaskan seperti bagan alir penelitian pada Gambar 1 berikut :
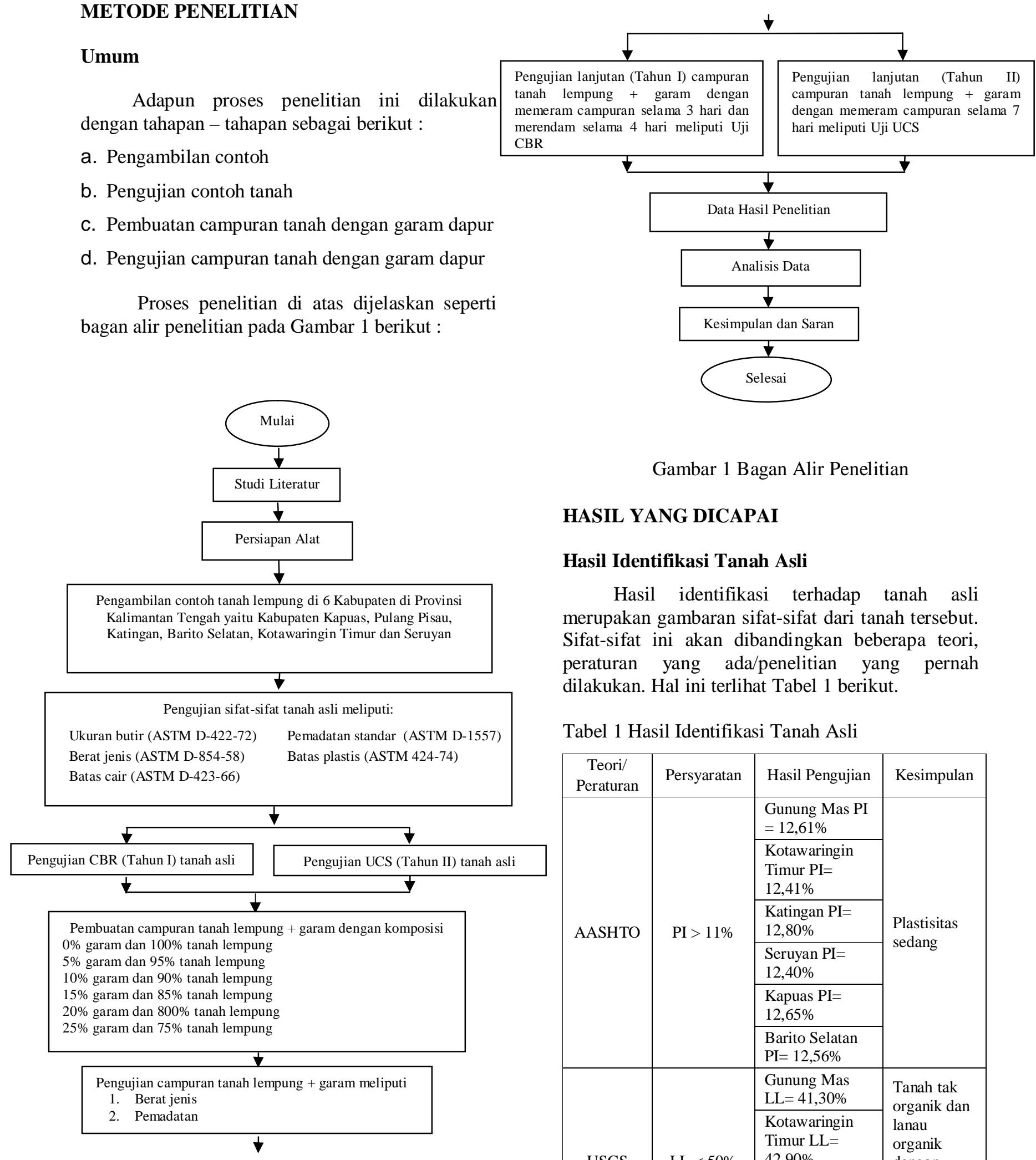

Gambar 1 Bagan Alir Penelitian

\section{HASIL YANG DICAPAI}

\section{Hasil Identifikasi Tanah Asli}

Hasil identifikasi terhadap tanah asli merupakan gambaran sifat-sifat dari tanah tersebut. Sifat-sifat ini akan dibandingkan beberapa teori, peraturan yang ada/penelitian yang pernah dilakukan. Hal ini terlihat Tabel 1 berikut.

Tabel 1 Hasil Identifikasi Tanah Asli

\begin{tabular}{|c|c|c|c|}
\hline $\begin{array}{c}\text { Teori/ } \\
\text { Peraturan }\end{array}$ & Persyaratan & Hasil Pengujian & Kesimpulan \\
\hline \multirow{6}{*}{ AASHTO } & \multirow{6}{*}{$\mathrm{PI}>11 \%$} & $\begin{array}{l}\text { Gunung Mas PI } \\
=12,61 \%\end{array}$ & \multirow{6}{*}{$\begin{array}{l}\text { Plastisitas } \\
\text { sedang }\end{array}$} \\
\hline & & $\begin{array}{l}\text { Kotawaringin } \\
\text { Timur PI= } \\
12,41 \%\end{array}$ & \\
\hline & & $\begin{array}{l}\text { Katingan PI= } \\
12,80 \%\end{array}$ & \\
\hline & & $\begin{array}{l}\text { Seruyan PI= } \\
12,40 \%\end{array}$ & \\
\hline & & $\begin{array}{l}\text { Kapuas PI= } \\
12,65 \%\end{array}$ & \\
\hline & & $\begin{array}{l}\text { Barito Selatan } \\
\mathrm{PI}=12,56 \%\end{array}$ & \\
\hline \multirow{4}{*}{ USCS } & \multirow{4}{*}{$\mathrm{LL}<50 \%$} & $\begin{array}{l}\text { Gunung Mas } \\
\mathrm{LL}=41,30 \%\end{array}$ & \multirow{4}{*}{$\begin{array}{l}\text { Tanah tak } \\
\text { organik dan } \\
\text { lanau } \\
\text { organik } \\
\text { dengan } \\
\text { plastisitas } \\
\text { rendah } \\
\text { sampai } \\
\text { sedang }\end{array}$} \\
\hline & & $\begin{array}{l}\text { Kotawaringin } \\
\text { Timur LL= } \\
42,90 \%\end{array}$ & \\
\hline & & $\begin{array}{l}\text { Katingan LL= } \\
44,90 \%\end{array}$ & \\
\hline & & $\begin{array}{l}\text { Seruyan LL= } \\
41,10 \%\end{array}$ & \\
\hline
\end{tabular}


Pemanfaatan Garam sebagai Bahan Stabilisasi Tanah Lempung...Hendra Cahyadi ${ }^{(1)}$, Nirwana Puspasari ${ }^{(2)}$

\begin{tabular}{|c|c|c|c|}
\hline $\begin{array}{c}\text { Teori/ } \\
\text { Peraturan }\end{array}$ & Persyaratan & Hasil Pengujian & Kesimpulan \\
\hline & & $\begin{array}{l}\text { Kapuas PI= } \\
43,50 \%\end{array}$ & $\begin{array}{l}\text { dalam } \\
\text { kelompok }\end{array}$ \\
\hline & & $\begin{array}{l}\text { Barito Selatan } \\
\mathrm{PI}=42,10 \%\end{array}$ & \\
\hline \multirow{6}{*}{$\begin{array}{l}\text { Atterberg } \\
\text { (1911) }\end{array}$} & \multirow{6}{*}{$7<\mathrm{PI}<17$} & $\begin{array}{l}\text { Gunung Mas PI } \\
=12,61 \%\end{array}$ & \multirow{6}{*}{$\begin{array}{l}\text { Lempung } \\
\text { berlanau } \\
\text { yang } \\
\text { kohesif } \\
\text { dengan } \\
\text { plastisitas } \\
\text { sedang }\end{array}$} \\
\hline & & $\begin{array}{l}\text { Kotawaringin } \\
\text { Timur PI= } \\
12,41 \%\end{array}$ & \\
\hline & & $\begin{array}{l}\text { Katingan PI= } \\
12,80 \%\end{array}$ & \\
\hline & & $\begin{array}{l}\text { Seruyan } \mathrm{PI}= \\
12,40 \%\end{array}$ & \\
\hline & & $\begin{array}{l}\text { Kapuas } \\
12,65 \%\end{array} \quad \mathrm{PI}=$ & \\
\hline & & $\begin{array}{l}\text { Barito Selatan } \\
\mathrm{PI}=42,10 \%\end{array}$ & \\
\hline \multirow{6}{*}{$\begin{array}{l}\text { Hardiyatm } \\
\text { o } \\
(2006)\end{array}$} & $\begin{array}{c}2,62<\text { Gs }< \\
2,68\end{array}$ & $\begin{array}{l}\text { Gunung Mas } \\
\mathrm{Gs}=2,670\end{array}$ & $\begin{array}{l}\text { Mengandun } \\
\mathrm{g} \text { lanau } \\
\text { organik }\end{array}$ \\
\hline & \multirow{2}{*}{$\begin{array}{c}2,68<\mathrm{Gs}< \\
2,75\end{array}$} & $\begin{array}{l}\text { Kotawaringin } \\
\text { Timur Gs= } \\
2,682\end{array}$ & \multirow{2}{*}{$\begin{array}{l}\text { Lempung } \\
\text { anorganik }\end{array}$} \\
\hline & & $\begin{array}{l}\text { Katingan } \mathrm{Gs}= \\
2,692\end{array}$ & \\
\hline & $\begin{array}{c}2,62<\text { Gs }< \\
2,68\end{array}$ & $\begin{array}{l}\text { Seruyan Gs= } \\
2,664\end{array}$ & $\begin{array}{l}\text { Mengandun } \\
\mathrm{g} \text { lanau } \\
\text { organik }\end{array}$ \\
\hline & $\begin{array}{c}2,68<\text { Gs }< \\
2,75\end{array}$ & $\begin{array}{l}\text { Kapuas Gs = } \\
2,684\end{array}$ & $\begin{array}{l}\text { Lempung } \\
\text { anorganik }\end{array}$ \\
\hline & $\begin{array}{c}2,62<\text { Gs }< \\
2,68\end{array}$ & $\begin{array}{l}\text { Barito Selatan } \\
\mathrm{Gs}=2,621 \%\end{array}$ & $\begin{array}{l}\text { Mengandun } \\
\mathrm{g} \text { lanau } \\
\text { organik }\end{array}$ \\
\hline \multirow{6}{*}{$\begin{array}{l}\text { Dirjen } \\
\text { Bina } \\
\text { Marga } \\
(1976)\end{array}$} & \multirow{6}{*}{$\begin{array}{c}3 \%<\mathrm{CBR} \\
<5 \%\end{array}$} & $\begin{array}{l}\text { Gunung Mas } \\
\text { CBR }=4,75 \%\end{array}$ & \multirow{6}{*}{$\begin{array}{l}\text { CBR tanah } \\
\text { dasar } \\
\text { (subgrade) } \\
\text { buruk }\end{array}$} \\
\hline & & $\begin{array}{l}\text { Kotawaringin } \\
\text { Timur CBR= } \\
4,00 \%\end{array}$ & \\
\hline & & $\begin{array}{l}\text { Katingan } \mathrm{CBR}= \\
4,60 \%\end{array}$ & \\
\hline & & $\begin{array}{l}\text { Seruyan CBR = } \\
4.55 \%\end{array}$ & \\
\hline & & $\begin{array}{l}\text { Kapuas CBR = } \\
4.75 \%\end{array}$ & \\
\hline & & $\begin{array}{l}\text { Barito Selatan } \\
\mathrm{CBR}=3.90 \%\end{array}$ & \\
\hline \multirow{5}{*}{$\begin{array}{l}\text { Bowles } \\
\text { (1993) }\end{array}$} & \multirow{5}{*}{$\begin{array}{c}3 \%<\mathrm{CBR} \\
<7 \%\end{array}$} & $\begin{array}{l}\text { Gunung Mas } \\
\text { CBR }=4,75 \%\end{array}$ & \multirow{5}{*}{$\begin{array}{l}\text { Poor to fair. } \\
\text { Jenis tanah } \\
\text { OH,CH,MH } \\
\text {,OL dan } \\
\text { A4,A5,A6, } \\
\text { A7 }\end{array}$} \\
\hline & & $\begin{array}{l}\text { Kotawaringin } \\
\text { Timur CBR= } \\
4,00 \%\end{array}$ & \\
\hline & & $\begin{array}{l}\text { Katingan } \mathrm{CBR}= \\
4,60 \%\end{array}$ & \\
\hline & & $\begin{array}{l}\text { Seruyan CBR = } \\
4.55 \%\end{array}$ & \\
\hline & & $\begin{array}{l}\text { Kapuas CBR = } \\
4.75 \%\end{array}$ & \\
\hline
\end{tabular}

\begin{tabular}{|c|l|l|l|}
\hline $\begin{array}{c}\text { Teori/ } \\
\text { Peraturan }\end{array}$ & Persyaratan & Hasil Pengujian & Kesimpulan \\
\hline & & $\begin{array}{l}\text { Barito Selatan } \\
\text { CBR }=3.90 \%\end{array}$ & \\
\hline
\end{tabular}

Sedangkan klasifikasi tanah berdasarkan sistem klasifikasi AASHTO dan USCS tanah asli di 6 kabupaten tersebut adalah sebagai berikut

Tabel 2 Klasifikasi Tanah Asli

\begin{tabular}{|c|l|l|}
\hline $\begin{array}{c}\text { Teori/ } \\
\text { peraturan }\end{array}$ & \multicolumn{1}{|c|}{ Lokasi } & \multicolumn{1}{|c|}{$\begin{array}{c}\text { Klasifikasi } \\
\text { Tanah }\end{array}$} \\
\hline \multirow{4}{*}{ AASHTO } & Gunung Mas & \\
\cline { 2 - 2 } & Kotawaringin Timur & \\
\cline { 2 - 2 } & Katingan & \\
& Seruyan & \\
& Kapuas & \\
& Barito Selatan & \\
& Gunung Mas & \\
& Kotawaringin Timur & \\
\cline { 2 - 2 } USCS & Katingan & \\
\cline { 2 - 2 } & Seruyan & \\
\cline { 2 - 3 } & Kapuas & \\
\cline { 2 - 3 } & Barito Selatan & \\
\hline
\end{tabular}

\section{Pemadatan Campuran Tanah dan Garam}

Adapun pemadatan campuran tanah dan garam dapat dilihat pada Gambar-Gambar berikut ini.

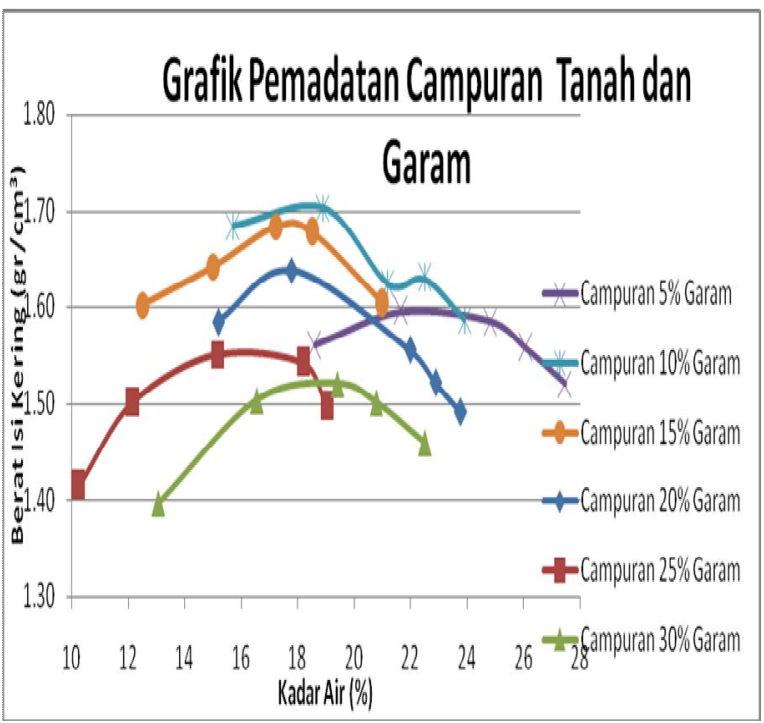

Media Ilmiah Teknik Sipil, Volume 6, Nomor 1, Desember 2017: 33-43 
Pemanfaatan Garam sebagai Bahan Stabilisasi Tanah Lempung...Hendra Cahyadi ${ }^{(1)}$, Nirwana Puspasari ${ }^{(2)}$

Gambar 2 Grafik Pemadatan Campuran Tanah dan Garam Lokasi Tanah Gunung Mas

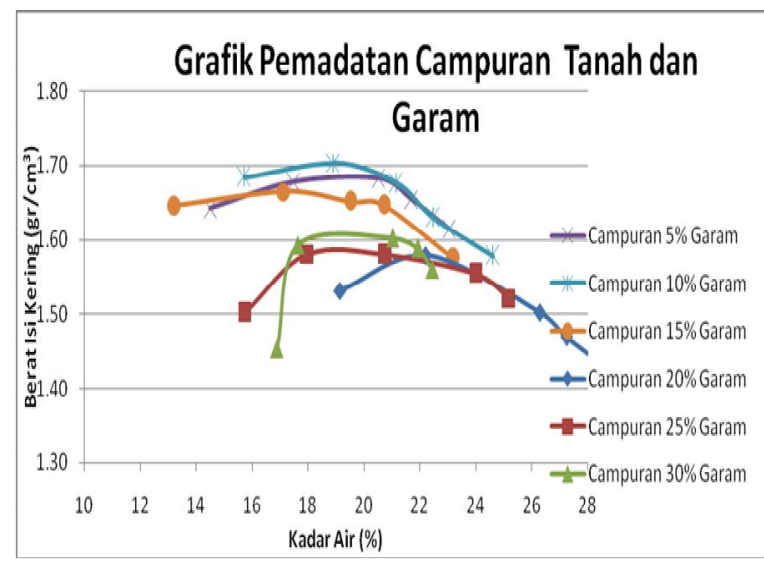

Gambar 3 Grafik Pemadatan Campuran Tanah dan Garam Lokasi Tanah Kotawaringin Timur

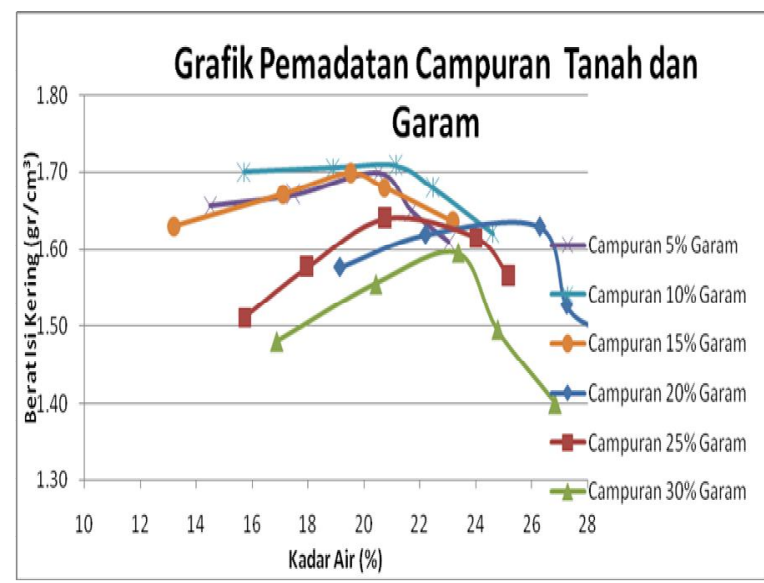

Gambar 4 Grafik Pemadatan Campuran Tanah dan Garam Lokasi Tanah Katingan

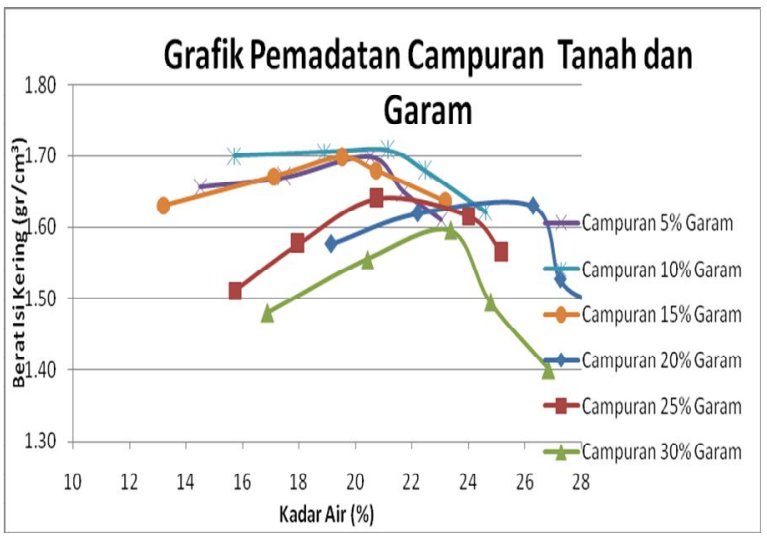

Gambar 5. Grafik Pemadatan Campuran Tanah dan Garam Lokasi Tanah Katingan

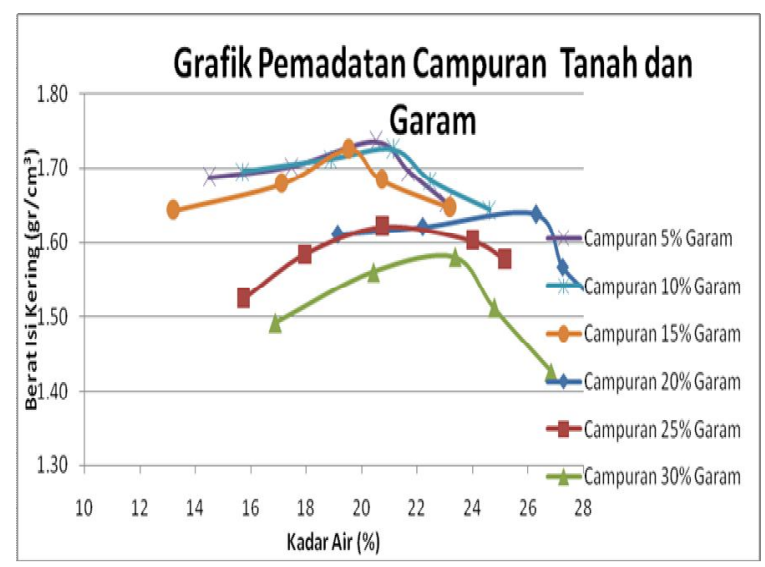

Gambar 6 Grafik Pemadatan Campuran Tanah dan Garam Lokasi Tanah Katingan

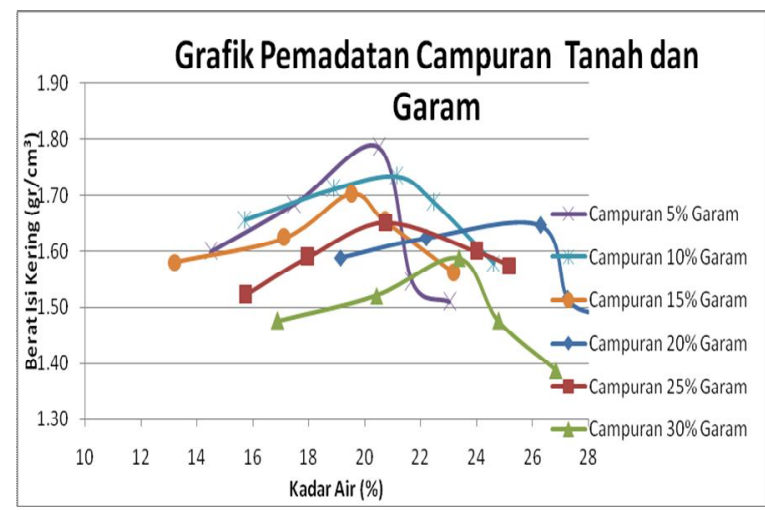

Gambar 7 Grafik Pemadatan Campuran Tanah dan Garam Lokasi Tanah Barito Selatan

Dari Gambar 52 sampai Gambar 7 diatas terlihat bahwa berat isi kering $\left(\gamma_{\mathrm{d}}\right)$ meningkat dengan pertambahan kadar air sampai akhirnya mencapai nilai optimumnya di satu titik yang disebut sebagai kadar air optimum (OMC). Setelah itu berat isi kering $\left(\gamma_{\mathrm{d}}\right)$ mengalami penurunan seiring dengan pertambahan kadar air.

\section{California Bearing Ratio (CBR) Campuran Tanah dan Garam}

Campuran tanah dan garam dengan persentase yang sudah ditentukan, diuji CBR nya. Ada enam kabupaten di Kalimantan Tengah yang diambil sampel tanahnya. Grafik akhir hasil 
penelitian CBR tanah yang distabilisasi dengan garam dengan variasi campuran dapat dilihat pada Gambar 8 berikut:

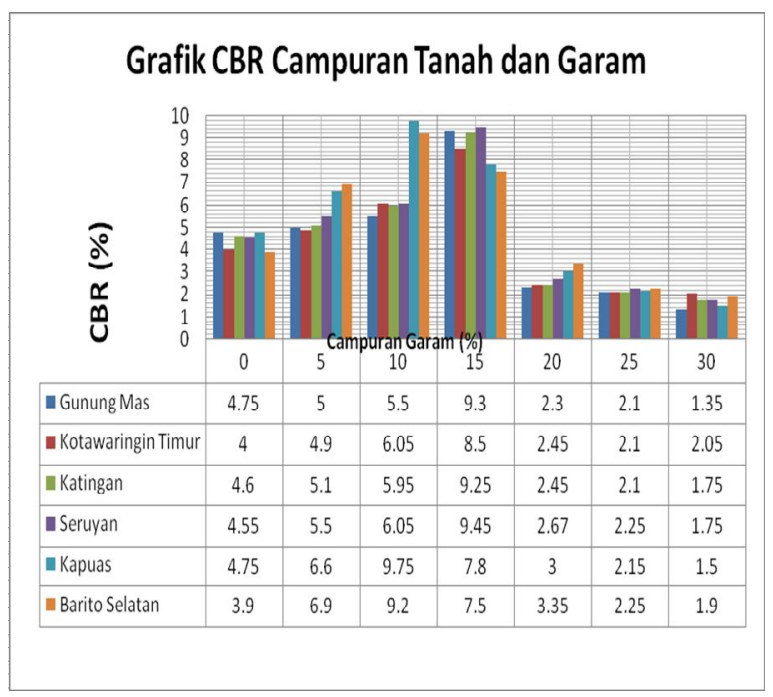

Gambar 8 Grafik CBR Campuran Tanah dan Garam

Dari Gambar 8 di atas, maka dapat disimpulkan bahwa penambahan garam dalam stabilisasi tanah di Kalimantan Tengah yang direkomendasikan adalah sebesar 10 sampai $15 \%$ dari berat tanah. Hal ini berdasarkan bahwa dengan campuran 10 sampai $15 \%$, nilai CBR yang dihasilkan oleh campuran tanah dan garam dapat memenuhi kriteria subgrade (tanah dasar) yang baik (Bina Marga) dan fair (Bowles). Bahkan menurut kriteria Bowles, lapisan tanah yang mempunyai kriteria fair dapat dijadikan subbase (lapisan sub pondasi).

\section{KESIMPULAN DAN SARAN}

\section{Kesimpulan}

1. Tanah asli di enam Kabupaten di Kalimantan Tengah yang diteliti berdasarkan hasil pengujian memiliki sifat plastisitas sedang dengan nilai PI berkisar antara $12,40 \%$ sampai $12,80 \%$. Memiliki batas cair berkisar antara $41,30 \%$ sampai $44,90 \%$ sehingga dapat dimasukkan ke klasifikasi CL/OL/ML. Nilai berat jenis (Gs) berkisar antara 2,621 sampai 2,692. CBR tanah asli berkisar antara 3,90\% sampai $4,75 \%$, sehingga dapat dikategorikan sebagai tanah yang memiliki daya dukung yang buruk/rendah. Berdasarkan sistem klasifikasi AASHTO tanah asli di atas termasuk dalam golongan tanah lempung dalam kelompok A-7-6. Sedangkan berdasarkan sistem klasifikasi USCS tanah asli
Desa Bukit Rawi masuk dalam kelompok tanah ML/OL.

2. Hasil stabilisasi tanah asli + garam dapur berdasarkan nilai persentase garam yang ditambahkan adalah terlihat pada tabel berikut ini

\begin{tabular}{|c|c|c|c|c|c|}
\hline \multirow[b]{2}{*}{ No } & \multirow[b]{2}{*}{ Lokasi Tanah } & \multirow[b]{2}{*}{ Kondisi } & \multirow{2}{*}{$\begin{array}{l}\text { Nilai } \\
\text { CBR }\end{array}$} & \multicolumn{2}{|c|}{ Kesimpulan } \\
\hline & & & & $\begin{array}{c}\text { Bina } \\
\text { Marga }\end{array}$ & Bowles \\
\hline \multirow[t]{7}{*}{1} & \multirow[t]{7}{*}{ Gunung Mas } & Asli & 4,75 & Buruk & $\begin{array}{l}\text { Poor to } \\
\text { fair }\end{array}$ \\
\hline & & $\begin{array}{l}5 \% \\
\text { Garam }\end{array}$ & 5,00 & Sedang & $\begin{array}{l}\text { Poor to } \\
\text { fair }\end{array}$ \\
\hline & & $\begin{array}{l}10 \% \\
\text { Garam }\end{array}$ & 5,50 & Sedang & $\begin{array}{l}\text { Poor to } \\
\text { fair }\end{array}$ \\
\hline & & $\begin{array}{l}15 \% \\
\text { Garam }\end{array}$ & 9,30 & Baik & Fair \\
\hline & & $\begin{array}{l}20 \% \\
\text { Garam }\end{array}$ & 2,30 & $\begin{array}{l}\text { Amat } \\
\text { buruk }\end{array}$ & $\begin{array}{l}\text { Very } \\
\text { poor }\end{array}$ \\
\hline & & $\begin{array}{l}25 \% \\
\text { Garam }\end{array}$ & 2,10 & $\begin{array}{l}\text { Amat } \\
\text { buruk }\end{array}$ & $\begin{array}{l}\text { Very } \\
\text { poor }\end{array}$ \\
\hline & & $\begin{array}{l}30 \% \\
\text { garam }\end{array}$ & 1,35 & $\begin{array}{l}\text { Amat } \\
\text { buruk }\end{array}$ & $\begin{array}{l}\text { Very } \\
\text { poor }\end{array}$ \\
\hline \multirow[t]{7}{*}{2} & \multirow[t]{7}{*}{ KotawaringinTimur } & Asli & 4,00 & Buruk & $\begin{array}{l}\text { Poor to } \\
\text { fair }\end{array}$ \\
\hline & & $\begin{array}{l}5 \% \\
\text { Garam }\end{array}$ & 4,90 & Buruk & $\begin{array}{l}\text { Poor to } \\
\text { fair }\end{array}$ \\
\hline & & $\begin{array}{l}10 \% \\
\text { Garam }\end{array}$ & 6,05 & Sedang & $\begin{array}{l}\text { Poor to } \\
\text { fair }\end{array}$ \\
\hline & & $\begin{array}{l}15 \% \\
\text { Garam }\end{array}$ & 8,50 & Baik & Fair \\
\hline & & $\begin{array}{l}20 \% \\
\text { Garam }\end{array}$ & 2,45 & $\begin{array}{l}\text { Amat } \\
\text { buruk }\end{array}$ & $\begin{array}{l}\text { Very } \\
\text { poor }\end{array}$ \\
\hline & & $\begin{array}{l}25 \% \\
\text { Garam }\end{array}$ & 2,10 & $\begin{array}{l}\text { Amat } \\
\text { buruk }\end{array}$ & $\begin{array}{l}\text { Very } \\
\text { poor }\end{array}$ \\
\hline & & $\begin{array}{l}30 \% \\
\text { garam }\end{array}$ & 2,05 & $\begin{array}{l}\text { Amat } \\
\text { buruk }\end{array}$ & $\begin{array}{l}\text { Very } \\
\text { poor }\end{array}$ \\
\hline \multirow[t]{6}{*}{3} & \multirow[t]{6}{*}{ Katingan } & Asli & 4,60 & Buruk & $\begin{array}{l}\text { Poor to } \\
\text { fair }\end{array}$ \\
\hline & & $\begin{array}{l}5 \% \\
\text { Garam }\end{array}$ & 5,10 & Sedang & $\begin{array}{l}\text { Poor to } \\
\text { fair }\end{array}$ \\
\hline & & $\begin{array}{l}10 \% \\
\text { Garam }\end{array}$ & 5,95 & Sedang & $\begin{array}{l}\text { Poor to } \\
\text { fair }\end{array}$ \\
\hline & & $\begin{array}{l}15 \% \\
\text { Garam }\end{array}$ & 9,25 & Baik & Fair \\
\hline & & $\begin{array}{l}20 \% \\
\text { Garam }\end{array}$ & 2,45 & $\begin{array}{l}\text { Amat } \\
\text { buruk }\end{array}$ & $\begin{array}{l}\text { Very } \\
\text { poor }\end{array}$ \\
\hline & & $\begin{array}{l}25 \% \\
\text { Garam }\end{array}$ & 2,10 & $\begin{array}{l}\text { Amat } \\
\text { buruk }\end{array}$ & $\begin{array}{l}\text { Very } \\
\text { poor }\end{array}$ \\
\hline
\end{tabular}


Pemanfaatan Garam sebagai Bahan Stabilisasi Tanah Lempung...Hendra Cahyadi ${ }^{(1)}$, Nirwana Puspasari ${ }^{(2)}$

\begin{tabular}{|c|c|c|c|c|c|}
\hline & & $\begin{array}{l}30 \% \\
\text { garam }\end{array}$ & 1,75 & $\begin{array}{l}\text { Amat } \\
\text { buruk }\end{array}$ & $\begin{array}{l}\text { Very } \\
\text { poor }\end{array}$ \\
\hline \multirow[t]{7}{*}{4} & \multirow[t]{7}{*}{ Seruyan } & Asli & 4,55 & Buruk & $\begin{array}{l}\text { Poor to } \\
\text { fair }\end{array}$ \\
\hline & & $\begin{array}{l}5 \% \\
\text { Garam }\end{array}$ & 5,50 & Sedang & $\begin{array}{l}\text { Poor to } \\
\text { fair }\end{array}$ \\
\hline & & $\begin{array}{l}10 \% \\
\text { Garam }\end{array}$ & 6,05 & Sedang & $\begin{array}{l}\text { Poor to } \\
\text { fair }\end{array}$ \\
\hline & & $\begin{array}{l}15 \% \\
\text { Garam }\end{array}$ & 9,45 & Baik & Fair \\
\hline & & $\begin{array}{l}20 \% \\
\text { Garam }\end{array}$ & 2,67 & $\begin{array}{l}\text { Amat } \\
\text { buruk }\end{array}$ & $\begin{array}{l}\text { Very } \\
\text { poor }\end{array}$ \\
\hline & & $\begin{array}{l}25 \% \\
\text { Garam }\end{array}$ & 2,25 & $\begin{array}{l}\text { Amat } \\
\text { buruk }\end{array}$ & $\begin{array}{l}\text { Very } \\
\text { poor }\end{array}$ \\
\hline & & $\begin{array}{l}30 \% \\
\text { garam }\end{array}$ & 1,75 & $\begin{array}{l}\text { Amat } \\
\text { buruk }\end{array}$ & $\begin{array}{l}\text { Very } \\
\text { poor }\end{array}$ \\
\hline \multirow[t]{7}{*}{5} & \multirow[t]{7}{*}{ Kapuas } & Asli & 4,75 & Buruk & $\begin{array}{l}\text { Poor to } \\
\text { fair }\end{array}$ \\
\hline & & $\begin{array}{l}5 \% \\
\text { Garam }\end{array}$ & 6,60 & Sedang & $\begin{array}{l}\text { Poor to } \\
\text { fair }\end{array}$ \\
\hline & & $\begin{array}{l}10 \% \\
\text { Garam }\end{array}$ & 9,75 & Baik & Fair \\
\hline & & $\begin{array}{l}15 \% \\
\text { Garam }\end{array}$ & 7,80 & Sedang & Fair \\
\hline & & $\begin{array}{l}20 \% \\
\text { Garam }\end{array}$ & 3,00 & $\begin{array}{l}\text { Amat } \\
\text { buruk }\end{array}$ & $\begin{array}{l}\text { Very } \\
\text { poor }\end{array}$ \\
\hline & & $\begin{array}{l}25 \% \\
\text { Garam }\end{array}$ & 2,15 & $\begin{array}{l}\text { Amat } \\
\text { buruk }\end{array}$ & $\begin{array}{l}\text { Very } \\
\text { poor }\end{array}$ \\
\hline & & $\begin{array}{l}30 \% \\
\text { garam }\end{array}$ & 1,50 & $\begin{array}{l}\text { Amat } \\
\text { buruk }\end{array}$ & $\begin{array}{l}\text { Very } \\
\text { poor }\end{array}$ \\
\hline \multirow[t]{7}{*}{6} & \multirow[t]{7}{*}{ Barito Selatan } & Asli & 3,90 & Buruk & $\begin{array}{l}\text { Poor to } \\
\text { fair }\end{array}$ \\
\hline & & $\begin{array}{l}5 \% \\
\text { Garam }\end{array}$ & 6,90 & Sedang & $\begin{array}{l}\text { Poor to } \\
\text { fair }\end{array}$ \\
\hline & & $\begin{array}{l}10 \% \\
\text { Garam }\end{array}$ & 9,20 & Baik & Fair \\
\hline & & $\begin{array}{l}15 \% \\
\text { Garam }\end{array}$ & 7,50 & Sedang & Fair \\
\hline & & $\begin{array}{l}20 \% \\
\text { Garam }\end{array}$ & 3,35 & Buruk & $\begin{array}{l}\text { Poor to } \\
\text { fair }\end{array}$ \\
\hline & & $\begin{array}{l}25 \% \\
\text { Garam }\end{array}$ & 2,25 & $\begin{array}{l}\text { Amat } \\
\text { buruk }\end{array}$ & $\begin{array}{l}\text { Very } \\
\text { poor }\end{array}$ \\
\hline & & $\begin{array}{l}30 \% \\
\text { garam }\end{array}$ & 1,90 & $\begin{array}{l}\text { Amat } \\
\text { buruk }\end{array}$ & $\begin{array}{l}\text { Very } \\
\text { poor }\end{array}$ \\
\hline
\end{tabular}

3. Secara umum hasil pengujian campuran tanah asli + garam berdasarkan parameter CBR menunjukan bahwa penambahan garam dapat meningkatkan $\mathrm{CBR}$ tanah dengan persentase terbaik adalah penambahan sebesar $10 \%$ sampai $15 \%$ garam dari berat tanah. Penambahan garam di atas $15 \%$ dari berat tanah akan menurunkan CBR tanah secara signifikan.

\section{Saran}

1. Perlu dilakukan pengujian pencampuran tanah + bahan material garam dengan memperbesar jumlah sampel.

2. Untuk penelitian lebih lanjut adalah mencari nilai kuat tekan bebas (UCS) tanah sebelum dan sesudah distabilisasi dengan garam.

3. Menentukan korelasi antara CBR dan UCS.

\section{DAFTAR PUSTAKA}

Bowles, J.E, (1993), Sifat-sifat fisik dan Geoteknis Tanah, Erlangga, Jakarta

Craig, R.F, (1987), Mekanika Tanah, Erlangga, Jakarta

Das, B.M, (1995), Mekanika Tanah (Prinsipprinsip Rekayasa Geoteknis), Erlangga, Jakarta

Diana, Willis., Afriza Marianti, Ika Ernawat, (2011), Optimasi Kadar Aspal Pada Stabilisasi Tanah Pasir Menggunakan Aspal Dengan Uji CBR. Jurnal Ilmiah Semesta Teknika Vol. 14, No. 2, 127-132, November 2011.

Hardiyatmo, HC, (2006), Mekanika Tanah 1, Edisi Keempat, Gajah Mada University Press, Yogyakarta.

Hardiyatmo, H.C, (2010), Stabilisasi Tanah Untuk Perkerasan Jalan, Gajah Mada University Press, Yogyakarta.

Hatmoko, J.T, (2000), Jurnal Tenik Sipil, Volume 8, No.1, 2007, Universitas Atma Jaya, Jogjakarta. 
Pemanfaatan Garam sebagai Bahan Stabilisasi Tanah Lempung...Hendra Cahyadi ${ }^{(1)}$, Nirwana Puspasari ${ }^{(2)}$

Ingles, O.G, dan Metcalf, J.B, (1972), Soil stabilization Principle and Practice, Butterworths Pty. Limited, Melbourne.

Muda, Anwar (2011), Stabilisasi Tanah Lempung Lempung Dengan Kadar Air Diatas OMC Terhadap Nilai CBR Dengan Dan Tanpa Rendaman Pada Tanah Lempung Organik. Jom F Teknik Volume 1 No.2 Oktober 2014.

Nasrullah,Oot (2010), Pengaruh Sodium Hidroksida (NaOH) Sebagai Bahan Stabilisasi Terhadap CBR Rendaman Dan Batas-Batas Konsistensi Tanah Lempung Bukit Rawi, Penelitian Skripsi, Program Studi Teknik Sipil, Universitas Muhammadiyah Palangkaraya.

Puspasari, Nirwana., Cahyadi, Hendra, (2015), Stabilisasi Tanah Lempung Palangka Raya Dengan Menggunakan Garam Dapur, Hibah Penelitian Dosen Pemula Kementerian Riset Teknologi dan Pendidikan Tinggi Tahun 2015

Respati, Sri, Filbert Reginald, Dan Yeni Yanuar, (2012), Pengaruh Penambahan Stone Dust Terhadap Nilai CBR Disain Pada Stabilisasi Tanah Cimanggis Dengan Mempertimbangkan Gradasi Stone Dust. Poli-Teknologi Vol.11 No.1, Januari 2012.

Sudjianto, Agus Tugas (2007), Stabilisasi Tanah Lempung Ekspansif Dengan Garam Dapur $(\mathrm{NaCl})$, Jurnal Teknik Sipil, Volume 8 Nomor 1, Fakultas Teknik, Universitas Adma Jaya, Yogyakarta.

Sukirman, S (1999), Perkerasan Lentur Jalan Raya, Nova, Bandung.

Widari, Lis Ayu, (2015), Pengaruh Penambahan Pasir Pada Tanah Lempung Terhadap Kuat Geser Tanah. Teras jurnal, Vol.5, No.2, September 2015

Yuniarti dkk (2008), Media Teknik Sipil, Jurusan Teknik Sipil, Universitas Mataram.

Zaro Khairatu, Soewignjo Agus Nugroho, Ferry Fatnanta, (2014), Pengaruh Kadar 